\title{
Research on the Environmental Accounting Information Disclosure of Listed Companies in Yunnan Province
}

\author{
Wei WENG, Quu-fang REN*, Chong-jiang DUAN* and Yang LI \\ Yunnan Normal University, Kunming, Yunnan, China \\ ${ }^{*}$ Corresponding author
}

\begin{abstract}
Keywords: Green Accounting; Accounting Reports; Environmental Accounting; Information Disclosure.
\end{abstract}

\begin{abstract}
The environmental accounting information disclosure of listed companies has been a topic of great concern in academic circles. From the perspective of environmental accounting information disclosure methods, this article analyzes the multi-dimensional aspects of 25 listed companies in Yunnan Province from 2014 to 2016, including their annual reports and social responsibility reports. The study finds that although the proportion of environmental accounting information disclosure by listed companies in Yunnan Province has been steadily increasing, there is a great disparity on the number of disclosures in different methods, showing a polarized distribution; and because the relevant departments do not provide a fixed disclosure method, the environmental accounting information disclosure by listed companies is not uniform, which increases the difficulty for users to inquire. China's listed companies only disclose environmental pollution, but substantive environmental governance work is inadequate. It is hoped that relevant authorities and government supervision departments will pay attention.
\end{abstract}

\section{Introduction}

In the 1970s, Research on Conversion of Social Costs in Pollution Control written by F.A. Beams (1971) and Accounting Problems of Pollution written by J.T. Martin (1973) opened a prelude to study environmental accounting overseas. In the West, economically well-developed countries in Europe and North America generally have higher levels of environmental accounting information disclosure. Many countries are leading in environmental accounting, such as the United States, Japan, Canada, and the European Union. Among them, Japan attaches great importance to environmental accounting, and has issued more than 10 standards and guidelines on environmental accounting in less than seven years.

China has not yet established a systematic, complete, operable and authoritative environment accounting information disclosure model. Regulations on environmental accounting information disclosure are also very few in China. Only the Announcement on the Environmental Information Disclosure of Listed Companies issued by the Ministry of Ecology and Environment of the P.R.C. (State Environmental Protection Administration) and the Measures for Environmental Information Disclosure of Enterprises and Institutions (Draft for Soliciting Opinions) in the China Environment Network are involved.

China's research on environmental accounting began in the 1990s. In 1992, Professor Ge Jiapeng and Professor Li Ruoshan co-published a thesis called A New Trend of Thought in Western Accounting Theory in the 1990s - Green Accounting Theory, which created a precedent for China's research on environmental accounting. The early scholars' research on environmental accounting was mostly normative, such as Meng Fanli (1999), Feng Gaina (2012), Liu Lingfeng (2016), Qian Hongguang, and $\mathrm{Hu}$ Yatian (2017). In recent years, scholars began to conduct empirical research on this issue, such as Jiang Linfeng (2010), Wen Yali and Chen Xuyan (2016), Cui Cheng and Wang Ling (2017), etc. However, compared with the research results of foreign scholars, China's research in this area is still not deep enough, for example, only the research on the annual report of listed companies. Given this situation, this article intends to take the listed companies in Yunnan Province as the research object and carries out research on the environmental accounting information 
disclosure status based on the published annual report, the report of the board of directors, social responsibility report and the independent report. Based on the research results, it proposes the main existing problems and corresponding countermeasures in hope to accelerate the environmental accounting information disclosure of listed companies and promote the progress of environmental protection in China.

\section{Analysis of the Environmental Accounting Information Disclosure Status of Listed Companies in Yunnan Province}

\subsection{Sample Selection and Data Sources}

By December 31, 2016, there were 32 listed companies in the Shanghai and Shenzhen Stock Exchanges in Yunnan Province. This article selected the annual reports, the reports of the board of directors, social responsibility reports and independent reports of these companies from 2014 to 2016 as the research content. Among them, Yi Xin Tang 002727, Long Jin 002750, KMCJNC 300505, Chuang Xin 002812 and Dali Pharmaceutical 603963 were listed after 2014, and ST stocks were excluded (ST YJFC 600265, ST YNYW 600725 and *ST KMJC 600806). As a result, a total of eight companies were excluded and 75 samples of data from 25 companies over three years were obtained. Since the environmental accounting information is not mandatory for disclosure in the annual report, the environmental accounting information disclosed by the listed companies in Yunnan Province in this paper is inquiries and statistics from documents, such as annual reports, board reports and social responsibility reports of 25 listed companies. The data involved in the research are mainly inquired through cninfo (http: //www.cninfo.com.cn), NetEase Finance Website (http://money.163.com) and Shanghai Stock Exchange (www.sse.com.cn). The final sample companies identified in this study are shown in Table 1.

Table 1. List of Sample Companies

\begin{tabular}{lll|lll|lll}
\hline S/N & Code & Name & S/N & Code & Name & S/N & Code & Name \\
\hline 1 & 000538 & $\begin{array}{l}\text { Yunnan } \\
\text { Baiyao }\end{array}$ & 10 & 002053 & YEIC & 19 & 600422 & KPC \\
\hline 2 & 000560 & 515J & 11 & 002059 & $\begin{array}{l}\text { Yunnan } \\
\text { Tourism }\end{array}$ & 20 & 600459 & SPM \\
\hline 3 & 000667 & MYHOME & 12 & 002114 & LPXD & 21 & 600497 & Ch Zn\&Ge \\
\hline 4 & 000807 & YNALCO & 13 & 002200 & Yuntou Ecology & 22 & 600792 & YNCE \\
\hline 5 & 000878 & YCC & 14 & 002265 & XYIC & 23 & 600883 & YBTI \\
\hline 7 & 000903 & Yunnei Power & 15 & 002428 & $\begin{array}{l}\text { Yunnan } \\
\text { Germanium }\end{array}$ & 24 & 600995 & WSDL \\
\hline 8 & 000960 & YTL & 17 & 600096 & YYTH & & & Pacific \\
\hline 9 & 002033 & $\begin{array}{l}\text { Lijiang } \\
\text { Tourism }\end{array}$ & 18 & 600239 & YMRD & & & \\
\hline
\end{tabular}

The sample data covers 9 industries. The specific industry classification distribution is shown in Table 2. Among them, there are 15 listed manufacturing companies, accounting for $60 \%$ of the total number of listed companies, which is the largest number of industries; there are 2 companies in real estate and tourism environment, each accounting for $8 \%$ of the total; there are 6 listed companies in other industries such as agriculture, forestry, animal husbandry and fishery, mining, wholesale and retail trade, finance, information technology, electricity, heat, gas and water production and supply, each accounting for $4 \%$ of the total. These companies together constitute the industry distribution of listed companies in Yunnan Province. 
Table 2. Industry Distribution Table of Listed Companies in Yunnan Province in 2017

\begin{tabular}{|c|c|c|c|c|c|c|c|c|c|}
\hline 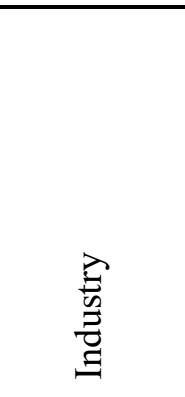 & 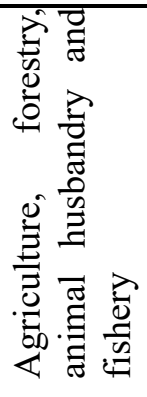 & $\stackrel{\infty}{\Xi} \underset{\Xi}{\Xi}$ & 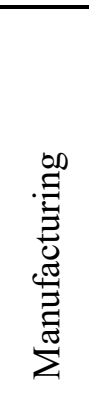 & 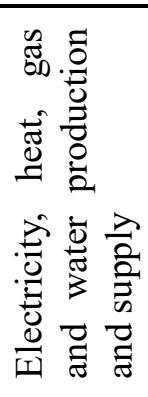 & 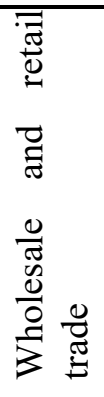 & $\begin{array}{l}\mathscr{\circlearrowright} \\
\text { 款 }\end{array}$ & 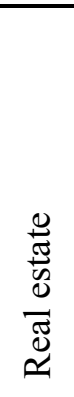 & 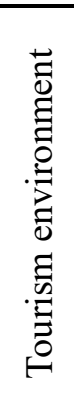 & 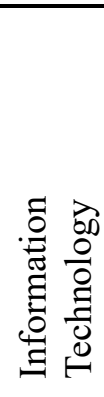 \\
\hline Quantity & 1 & 1 & 15 & 1 & 1 & 1 & 2 & 2 & 1 \\
\hline Proportion & $4 \%$ & $4 \%$ & $60 \%$ & $4 \%$ & $4 \%$ & $4 \%$ & $8 \%$ & $8 \%$ & $4 \%$ \\
\hline
\end{tabular}

\subsection{Situation of Environmental Accounting Information Disclosure Methods}

Table 3. Overall Situation of Environmental Accounting Information Disclosure of Listed Companies in Yunnan Province from 2014-2016 (A total of 75 samples)

\begin{tabular}{l|c|c|c|c|c|c}
\hline \multirow{2}{*}{ Disclosure Method } & \multicolumn{2}{|c|}{2014} & \multicolumn{2}{c|}{2015} & \multicolumn{2}{c}{2016} \\
\cline { 2 - 7 } & $\begin{array}{c}\text { Disclosure } \\
\text { Quantity }\end{array}$ & $\begin{array}{c}\text { Disclosure } \\
\text { Rate }\end{array}$ & $\begin{array}{c}\text { Disclosure } \\
\text { Quantity }\end{array}$ & $\begin{array}{c}\text { Disclosure } \\
\text { Rate }\end{array}$ & $\begin{array}{c}\text { Disclosure } \\
\text { Quantity }\end{array}$ & $\begin{array}{c}\text { Disclosure } \\
\text { Rate }\end{array}$ \\
\hline Annual Report & 22 & $88 \%$ & 22 & $88 \%$ & 24 & $96 \%$ \\
\hline $\begin{array}{l}\text { Report of the Board } \\
\text { of Directors }\end{array}$ & 12 & $48 \%$ & 13 & $52 \%$ & 15 & $60 \%$ \\
\hline $\begin{array}{l}\text { Social Responsibility } \\
\text { Report }\end{array}$ & 7 & $28 \%$ & 7 & $28 \%$ & 7 & $28 \%$ \\
\hline Independent Report & 0 & $0 \%$ & 0 & $0 \%$ & 0 & $0 \%$ \\
\hline
\end{tabular}

Note: A company may use multiple ways to disclose environmental accounting information

From Table 3, it can be seen that the listed companies in Yunnan Province have changed their methods, quantity and proportion of environmental accounting information disclosure from 2014 to 2016 to varying degrees. In 2014, only 22 out of the 25 listed companies in Yunnan Province disclosed environmental information through annual reports, accounting for 88\%; in 2016, two more listed companies were added, with a total of 24 companies disclosing environmental information by annual reports, accounting for $96 \%$. Basically, the environmental accounting information of all listed companies will be disclosed in the annual report. It can also be seen that as the governments of all levels in our country attach importance to environmental protection and environmental accounting, the listed companies also responded to the policies of the government and to China's environmental accounting information disclosure model accordingly.

At the same time, from 2014 to 2016, the number of listed company companies in Yunnan Province that disclosed the company's environmental information through the report of the board of directors gradually increased. However, there are few listed companies that disclose the environmental accounting information through the preparation of social responsibility reports. From 2014 to 2016, only 7 companies, including Yunnan Yuntianhua Co., Ltd, KPC Pharmaceuticals, Inc., Sino-platinum Metals Co., Ltd, Chihong Zinc \& Germanium Co., Ltd, Yunnan Coal \& Energy Co., Ltd, Yunnan Wenshan Electric Power Co., Ltd, and The Pacific Securities Co., Ltd.As can be seen from Figure 1, from 2014 to 2016, among the four ways in which 25 listed companies in Yunnan Province disclosed their environmental accounting information, annual report was mostly used by the companies, nearly $100 \%$; the number of companies that disclosed through the social responsibility report was the least, and there was no change from 2014 to 2016, which was stable at $28 \%$; the environmental information disclosure through independent report has always been zero. From the analysis of Figure 1, the disclosure rate of environmental information of listed companies in Yunnan Province has been continuously rising. By 2016, companies that did not disclose environmental accounting information in 2014 began to recognize the importance of environment to varying degrees. The awareness of environmental protection and environmental accounting has 
been greatly improved.

In summary, from the overall situation of 25 listed companies disclosure from 2014 to 2016, the proportion of environmental accounting information disclosure by listed companies in Yunnan Province has been steadily increasing, but there is a great disparity between the disclosure number of different disclosure methods, showing a polarized distribution, and because the relevant departments do not provide a fixed disclosure method, the disclosure of environmental accounting information in listed companies is not uniform, which increases the difficulty of user inquiries.

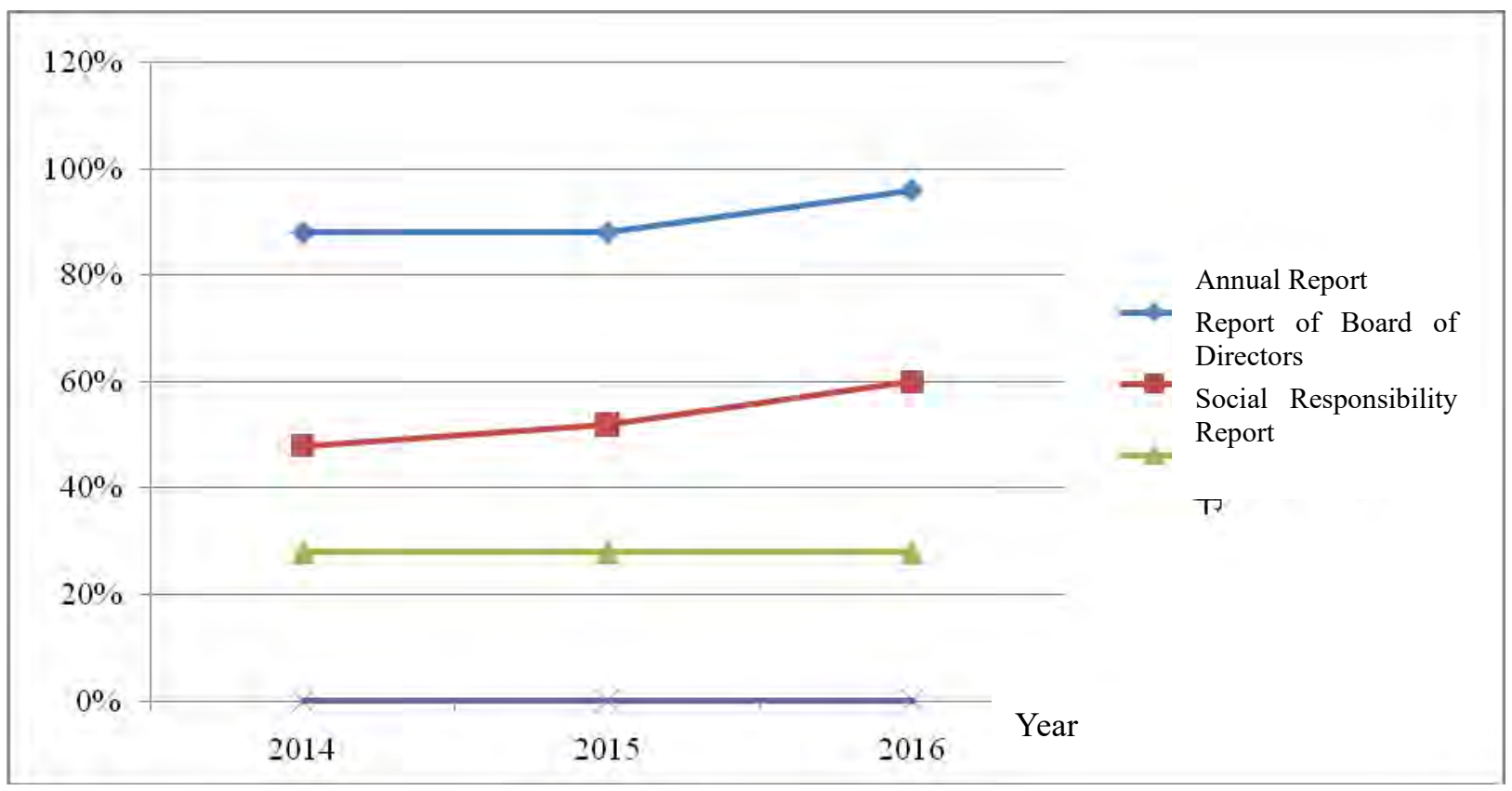

Figure 1. The Line Chart of Environmental Accounting Information Disclosure of Listed Companies in Yunnan Province, 2014-2016

\subsection{Disclosure of Related Contents of Environmental Accounting Information}

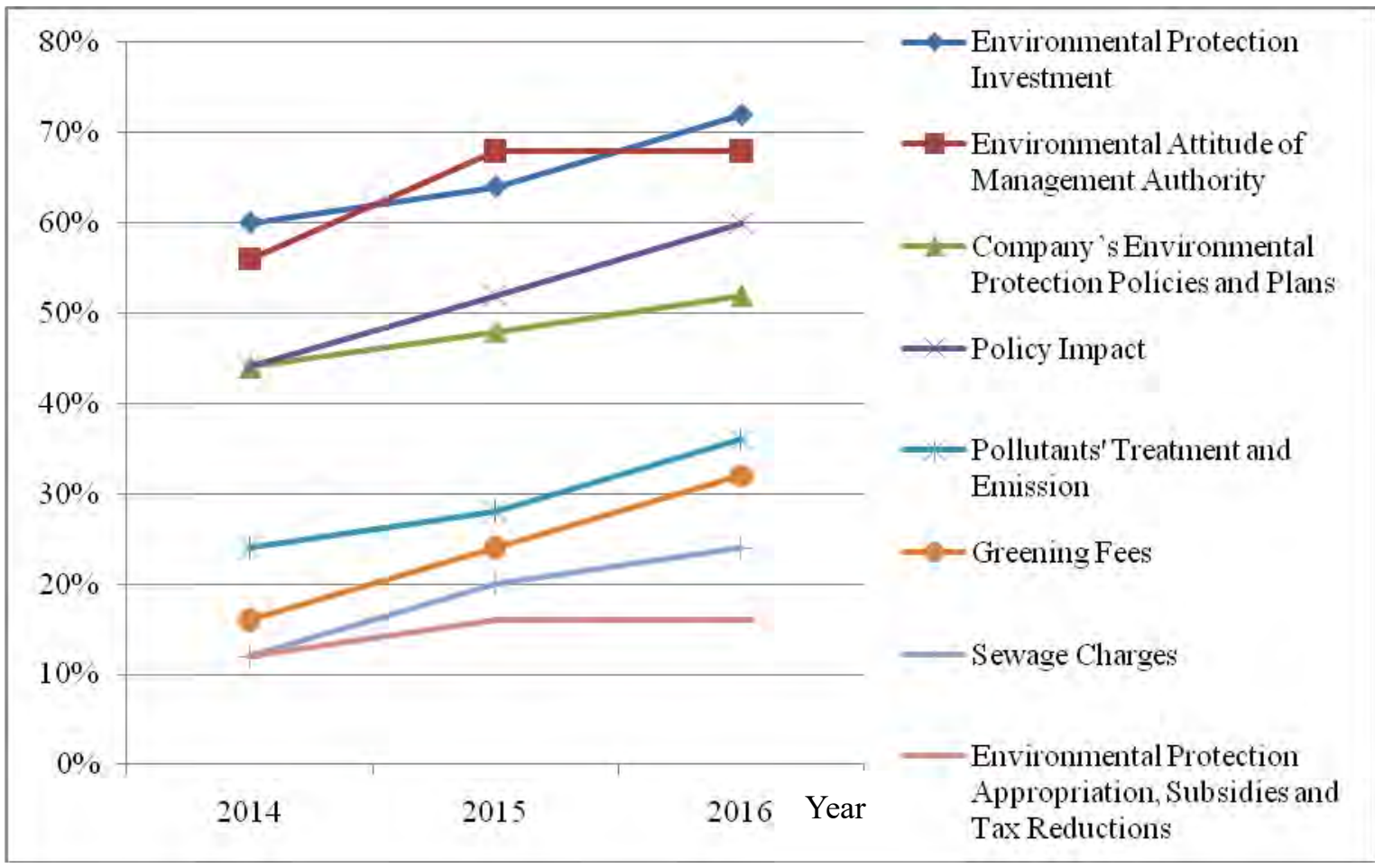

Figure 2. The Overall Situation of Environmental Accounting Information Disclosure of Listed

Companies in Yunnan Province from 2014 to 2016 
Table 4. The Overall Situation of Environmental Accounting Information Disclosure of Listed Companies in Yunnan Province from 2014 to 2016 (A total of 75 samples)

\begin{tabular}{|c|c|c|c|c|c|c|c|}
\hline \multirow{2}{*}{$\begin{array}{l}\text { Disclosure } \\
\text { Items }\end{array}$} & \multirow{2}{*}{$\begin{array}{l}\text { Quantity of } \\
\text { Listed } \\
\text { Companies }\end{array}$} & \multicolumn{2}{|c|}{2014} & \multicolumn{2}{|c|}{2015} & \multicolumn{2}{|c|}{2016} \\
\hline & & $\begin{array}{c}\text { Disclosure } \\
\text { Quantity }\end{array}$ & $\begin{array}{l}\text { Disclosu } \\
\text { re Rate }\end{array}$ & $\begin{array}{c}\text { Disclosure } \\
\text { Quantity }\end{array}$ & $\begin{array}{l}\text { Disclosu } \\
\text { re Rate }\end{array}$ & $\begin{array}{c}\text { Disclosure } \\
\text { Quantity }\end{array}$ & $\begin{array}{c}\text { Disclosu } \\
\text { re Rate }\end{array}$ \\
\hline $\begin{array}{l}\text { Environmental } \\
\text { Protection } \\
\text { Investment }\end{array}$ & \multirow{8}{*}{25} & 15 & $60 \%$ & 16 & $64 \%$ & 18 & $72 \%$ \\
\hline $\begin{array}{l}\text { Environmental } \\
\text { Attitude of } \\
\text { Management } \\
\text { Authority }\end{array}$ & & 14 & $56 \%$ & 16 & $68 \%$ & 17 & $68 \%$ \\
\hline $\begin{array}{l}\text { Company's } \\
\text { Environmental } \\
\text { Protection } \\
\text { Policies and } \\
\text { Plans }\end{array}$ & & 11 & $44 \%$ & 12 & $48 \%$ & 13 & $52 \%$ \\
\hline Policy Impact & & 11 & $44 \%$ & 13 & $52 \%$ & 15 & $60 \%$ \\
\hline $\begin{array}{l}\text { Pollutants } \\
\text { Treatment and } \\
\text { Emission }\end{array}$ & & 6 & $24 \%$ & 7 & $28 \%$ & 9 & $36 \%$ \\
\hline Greening Fees & & 4 & $16 \%$ & 6 & $24 \%$ & 8 & $32 \%$ \\
\hline $\begin{array}{l}\text { Sewage } \\
\text { Charges }\end{array}$ & & 3 & $12 \%$ & 5 & $20 \%$ & 6 & $24 \%$ \\
\hline $\begin{array}{l}\text { Environmental } \\
\text { Protection } \\
\text { Appropriation, } \\
\text { Subsidies and } \\
\text { Tax Reductions }\end{array}$ & & 3 & $12 \%$ & 4 & $16 \%$ & 4 & $16 \%$ \\
\hline
\end{tabular}

Note: A company may disclose multiple contents of environmental accounting information.

From the general sense, the related contents of environmental accounting information disclosure mainly focus on the process of daily management of listed companies, which mainly includes environmental pollution, environmental protection and costs of environmental development, etc. This article concludes the overall situation of environmental accounting information disclosure of listed companies in Yunnan province from 2014 to 2016 by analyzing and summarizing 75 samples of 25 listed companies. The details are shown in Table 4. The data in the table shows that the environmental protection investment and the environmental attitude of management authority hold the highest proportion in the disclosed items, which accounts for $72 \%$ and $68 \%$ respectively in 2016 . The company's environmental protection policies and plans and policy impact have a moderate proportion, while environmental protection appropriation, subsidies and tax reductions, sewage charges, greening fees, pollutant treatment and emission account for a low proportion relatively. From the combined analysis of Table 4 and Figure 2, it can be concluded that management authorities can clearly understand the importance of environmental accounting information disclosure under the requirement and guidance of national policies and listed companies can voluntarily make the company's own environmental protection policies and plans after being affected by policies on environmental protection and invest in construction projects for environmental protection. However, compared with other regions, the listed companies in Yunnan Province disclose limited contents of environmental accounting information relatively. Most listed companies' environmental protection investment and policy making only stay on the surface. Substantial environmental expenditures and environmental governance work are still relatively insufficient (as evidenced by the relatively low sewage charges and greening fees). Even some companies' annual reports only describe the environmental pollution caused by the discharged pollutants, whether the company has taken corresponding measures to manage the pollution hasn't 
been explained. And Zhang Min (2012) found similar results based on the annual report data of listed companies in Jiangsu Province [16].

\section{Conclusion}

In recent years, China's environmental protection work has achieved certain results. However, judging from the national situation, the social responsibilities of listed companies and public environmental awareness need to be strengthened. The government supervision departments can guide the listed company to develop from mandatory disclosure to conscious disclosure by making laws and regulations or administrative means. At the same time, in order to achieve sustainable economic development, listed companies should comply with the needs of the times and the trend of economic development to disclose more valuable, complete and comprehensive environmental accounting information. The research of this article only starts from the listed companies in Yunnan Province, so there are still some limitations. The research on environmental accounting information disclosure of listed companies can be further supplemented.

\section{References}

[1] Liu Genxia. An Empirical Analysis of Environmental Information Disclosure of Listed Companies in Henan Province [N]. Journal of Henan Business College, 2008-07-15 (4).

[2] Meng Fanli. On the Environmental Accounting Information Disclosure and Related Theoretical Problems [J]. Accounting Research, 1999, 4: 16-25.

[3] Li Xinhe, Zhu Lijiao. The Supply and Demand Quality of Accounting Information and Harmony Approach of Contradiction [J]. Shanghai Accounting, 2000, 7: 8-11.

[4] Xiao Xu. On the Theoretical Structure of Environmental Accounting [J]. Collected Essays on Finance and Economics, 2002, 4: 58-63.

[5] Zhu Ji. A Correlation Research of Environmental Accounting Information Disclosure and the Cost of Equity Capital [D]. Changsha: Hunan University, 2011

[6] Song Ziyi. Research on Environmental Accounting Information Disclosure [M]. Beijing: China Social Sciences Press, 2012, 79-81.

[7] Feng Gaina. Analysis of Environmental Accounting Information Disclosure — Taking Listed Companies in Yunnan Province as an Example [J]. Communication of Finance and Accounting, 2012, 11: 19-21.

[8] Xiao Yue. Status Analysis of Environmental Accounting Information Disclosure - Taking the Listed Companies in the Coal Industry as an Example [J]. Green Finance and Accounting, 2015, 12: 47-51.

[9] Liu Lingfeng. Research on Environmental Accounting Information Disclosure of Listed Companies in Yunnan Province [J]. Times Finance, 2016, 3: 174-175.

[10] Qian Hongguang, $\mathrm{Hu}$ Yatian. Discussion on the Problems and Countermeasures of Environmental Accounting Information Disclosure of Listed Companies [J]. China Journal of Commerce, 2017, 3: 212-122.

[11] Li Jianfa, Xiao Hua. China's Corporate Environmental Report: Status Quo, Demand and Future [J]. Accounting Research, 2002, 4: 52-50.

[12] Jiang Linfeng. Corporate Governance, Financial Status and Environmental Accounting Information Disclosure [J]. Communication of Finance and Accounting, 2010, 6: 21-23.

[13] Wang Xiaohong, Wang Haimin, Li Binquan. A Study on the Influence Effect Domain of Environmental Accounting Information Disclosure of Listed Companies - Taking Listed 
Companies in Shaanxi Province as an Example [J]. Modern Economic Science, 2011, 4: 115-128.

[14] Wen Yali, Chen Xuyan. An Empirical Study on Environmental Accounting Information Disclosure of Listed Companies [J]. Modern Business, 2016, 23: 142-144.

[15] Cui Cheng, Wang Ling. An Empirical Study on the Effect of Environmental Accounting Information Disclosure Quality on Corporate Value - Taking the Listed Companies in the Mining Industry as an Example [J]. Financial Accounting Analysis, 2017, 3: 49-56.

[16] Zhang Min. Research on the Environmental Accounting Information Disclosure Problems of Listed Companies in China - Taking the Listed Companies in Shanghai and Shenzhen Stock Exchanges and Jiangsu Equity Exchange Center as an Example [J]. The House of Ideas on Stock Market, 2012, 12: 82-83.

[17] Zhang Lu. Research on the Environmental Accounting Information Disclosure Problems of Listed Companies [J]. Business Economy, 2017, 4: 171-173.

[18] Li Zhuping, Ban Huifang, Yu Hao. Research on Environmental Accounting Information Disclosure of Listed Mining Companies [J]. Friends of Accounting, 2015, 20: 21-25.

[19] Guo Xiuzhen. Environmental Protection and Corporate Environmental Accounting Information Disclosure - Analysis of Empirical Data of Listed Companies Based on Corporate Governance Structure [J]. Research on Financial and Economic Issues, 2013, 5: 116-121.

[20] Tian Xiangyu, He Beibei. Research on Environmental Accounting Information Disclosure of Listed Coal Companies - Taking the Listed Coal Companies in Shanxi Province as an Example [J]. Friends of Accounting, 2014, 3: 81-85.

[21] Smith V. Environmental problems in China, estimates of economic cost [J]. New York: East-West Center Special, 1996 (2): 71-73.

[22] Bartelmus Pete. Integrated environmental and economic accounting methods and applications [J]. Journal of Official Statistics, 1993, 9 (1): 179-182.

[23] Slam M. A., Mathews M. R. Grameen bank's social performance disclosure-responding to a negative assessment by Wall Street Journal in late 2001 [J]. Asian Review of Accounting, 2009, 17 (2): 149-162. 